Summer 2014

\title{
Epistemologies of the South and Human Rights: Santos and the Quest for Global and Cognitive Justice
}

Jose-Manuel Barreto

University of Bonn, barreto@uni-bonn.de

Follow this and additional works at: https://www.repository.law.indiana.edu/ijgls

Part of the Human Rights Law Commons, International Law Commons, Law and Philosophy Commons, and the Legal History Commons

\section{Recommended Citation}

Barreto, Jose-Manuel (2014) "Epistemologies of the South and Human Rights: Santos and the Quest for Global and Cognitive Justice," Indiana Journal of Global Legal Studies: Vol. 21 : Iss. 2 , Article 1.

Available at: https://www.repository.law.indiana.edu/ijgls/vol21/iss2/1

This Article is brought to you for free and open access by the Law School Journals at Digital Repository @ Maurer Law. It has been accepted for inclusion in Indiana Journal of Global Legal Studies by an authorized editor of Digital Repository@Maurer Law. For more information, please contactrvaughan@indiana.edu.

\section{$\Psi$}

JEROME HALL LAW LIBRARY

INDIANA UNIVERSITY

Maurer School of Law
Bloomington 


\title{
Epistemologies of the South and Human Rights: Santos and the Quest for Global and Cognitive Justice
}

\author{
JOSÉ-MANUEL BARRETO*
}

\begin{abstract}
This article offers an introduction to Boaventura de Sousa Santos's general philosophical orientation, explores the concepts of "abyssal thinking" and "epistemologies of the South," and draws consequences for the theory of human rights, taking into consideration the idea of rewriting the history of rights in the context of colonialism and Santos's proposal of a post-abyssal conception of rights and intercultural dialogue. This piece ends with some considerations on the cultural and political conditions for advancing a new understanding of human rights.
\end{abstract}

\section{INTRODUCTION}

Today, epistemology is one of the key sites of the critique of modernity and the Eurocentric bias of knowledge and human rights. Many voices and theories of knowledge are emerging from the Global South, including the "geopolitics of knowledge" elaborated by Enrique Dussel and Walter Mignolo in the field of decolonial theory, ${ }^{1}$ those developed from subaltern studies like Dipesh Chakrabarty's Provincializing Europe, ${ }^{2}$ and those establishing a link between law and

* Rechtskulturen Post-Doctoral Fellow, Juristische Fakultät, Humboldt Universität zu Berlin. I would like to thank Cesar Baldi, Julia Suárez-Krabbe, and Tsepo Madlingozi for their insights into Santos's work. This article is dedicated to Sonia.

1. See Walter D. Mignolo, The Geopolitics of Knowledge and the Colonial Difference, 101 S. ATLANTIC Q. 57 (2002).

2. See generally Dipesh Chakrabarty, Provinciallzing Europe: Postcolonial Thought AND Historical. Difference (Sherry B. Ortner et al. eds., reissue ed. 2008) (presenting the idea of "provincializing aEurope," which removes the philosophical universalist mask that hides the spatial and historical attachments and limits of European thought). See also Martin Woessner, Provincializing Human Rights? The Heideggerian Legacy from Charles Malik to Dipesh Chakrabarty, in HUMAN RIGHTS FROM A THIRd WORLd PERSPECTIVE: CRITIQUe, History AND INTERnATIONAL LAW 65 (José-

Indiana Journal of Global Legal Studies Vol. 21 \#2 (Summer 2014)

(C) Indiana University Maurer School of Law 
globalization like William Twining's General Jurisprudence. ${ }^{3}$ Boaventura de Sousa Santos's "post-abyssal thinking" or "epistemologies of the South" occupies a place in this contemporary uprising that looks for new paradigms of thought.

These new epistemological theories depart from a critique of Eurocentrism, while at the same time have canonical modern theories of knowledge among their antecedents. In the history of Western epistemology, it is uncommon to find a link between truth and politics, or to find justice adopted as an overriding concern. On the contrary, in the tradition of the dominant European subjectivism from René Descartes and Immanuel Kant to Edmund Husserl-and in analytical philosophy-the investigation of the relations between the subject and the object is motivated by breaking the attachments of consciousness to the world and searching for objectivity. To point to epistemologies orientated by political or economic questions, it is necessary to bring to the fore Marx's historical materialism. Another more contemporary example is Richard Rorty's neopragmatism and its priority of solidarity. ${ }^{4}$ Related to both materialism and pragmatism, ${ }^{5}$ but shifting the point of view to the Global South and globalizing the framework of analysis, Santos's epistemologies of the South are at the center of his reflection on the colonial division between North and South, which permeates knowledge in modernity, as well as the quest for global justice. The point of departure of this political epistemology is a critical characterization of modern reason as an abyssal thinking, one that operates by establishing and radicalizing distinctions between knowledge elaborated in the North and in the South. ${ }^{6}$

The epistemologies of the South gravitate, first of all, toward issues of the production of knowledge and, in particular, the ways in which we can think of and transform the social sciences and legal theory. However, this reflection is not only epistemological, it also has

Manuel Barreto ed., 2013) [hereinafter THIRD WORLD PERSPECTIVE] (outlining the idea of provincializing human rights in both the "new" and "old" world).

3. See generally WILLIAM TWINING, GENERAL JURISPRUDENCE: UNDERSTANDING LAW FROM A GLOBAL PERSPECTIVE (2009) (calling into evidence the blinding effects of the parochialism of Western legal theory).

4. See generally RICHARD RORTY, CONTINGENCY, IRONY, AND SOLIDARITY (1989) (proposing a political culture in which individuals have self-awareness about the contingency of their own convictions and embrace solidarity as their key virtue).

5. See Boaventura de Sousa Santos et al., Introduction: Opening up the Canon of Knowledge and Recognition of Difference, in ANOTHER KNOWLEDGE IS POSSIBLE: BEYOND NORTHERN EPISTEMOLOGIES, at xix, xxxi (Boaventura de Sousa Santos ed., 2007) [hereinafter ANOTHER KNOWLEDGE].

6. See Boaventura de Sousa Santos, Beyond Abyssal Thinking: From Global Lines to Ecologies of Knowledges, 30 REv. (FERNAND BRAUDEL CTR.) 45 (2007). 
important political origins and consequences, too. For those thinking from the:perspective of the South, the problem faced today by the social sciences, law, and human rights is that of how to advance the quest for global justice in the times of neoliberal globalization and neocolonialism. The economic and political injustices that characterize the world order today result in, and are sustained by, the cognitive injustice that exists at the core of the production of knowledge since the beginnings of the modern colonization of the world. These injustices are intertwined, and constitute and feed each other. It is within this horizon that Santos states that the struggle for global justice includes the search for epistemic justice. In other words, "political resistance needs to be premised upon epistemological resistance." 7 And this is one of the prevailing interests that orientate Santos's theoretical work.

Santos's engagement with human rights is long dated to and set in the crisis of revolution and socialism as emancipatory discourses. The question orientating Santos's reflection is that about the possibility of human rights becoming a new language of emancipation and progressive politics, one able to give impulse and incarnate counterhegemonic "struggles [that] aim at changing the social structures that are accountable for systemically produced unjust human suffering." After acknowledging the historical use of human rights for regulation and domination, Santos responds positively to this interrogation. However, their capacity for emancipation is conditioned to human rights being reimagined by an intercultural dialogue between Western and non-Western conceptions of rights. ${ }^{9}$ Crucially, when Santos relates human rights to liberation and justice, he is not only considering the issue of social justice in national scenarios, but also the capacity of rights to advance the quest for equality and justice in a global context. Thus, Santos approaches human rights with the aim of strengthening their emancipatory power in the world as a whole-advanced by social movements struggling for justice-by relying on the global appeal and local, culturally grounded legitimacy of human rights. ${ }^{10}$

In this order of ideas, this article (I) offers a summary introduction to Santos's general philosophical orientation, (II) explores the concepts of abyssal thinking and (III) epistemologies of the South, (IV) draws

7. Id. at 63 .

8. Boaventura de Sousa Santos, If God were a Human Rights Activist: Human Rights and the Challenge of Political Theologies, 2009 LAW Soc. JUST. \& GLOBAL DEV. 1, 26, available at http://www.go.warwick.ac.uk/elj/gd/2009_1/santos.

9. See Boaventura de Sousa Santos, Human Rights as an Emancipatory Script? Cultural and Political Conditions, in ANOTHER KNOWLEDGE, supra note 5, at 3, 4.

10. Boaventura de Sousa Santos, De la Mano de Alicia: lo social y lo POLÍtico EN LA POSTMODERNIDAD 345-47 (Consuelo Bernal \& Mauricio García Villegas trans., 1998) (Colom.). 
some consequences for the theory of human rights, (V) takes into consideration the idea of rewriting the history of rights in the context of colonialism, and (VI) considers Santos's proposal of a post-abyssal conception of rights and intercultural dialogue. This piece ends with some considerations on the cultural and political conditions for advancing such a new understanding of human rights.

\section{THE CRITIQUe OF EUROCENTRISM AND FROM THE POSTMODERN TO THE POSTCOLONIAL}

The social sciences, the humanities, and legal theory are traversed today by the critique of Eurocentrism, with some cutting-edge disciplines already finding an exit to this impasse in the "decolonization" of knowledge. Whether in sociology,"1 international relations, ${ }^{12}$ legal history, ${ }^{13}$ international law, ${ }^{14}$ or human rights, ${ }^{15}$ we are witnesses to the urgency of pointing at the previously invisible structure or bias that limits the legitimacy and validity of wellestablished and canonical corpuses of knowledge. There is a growing concern for discerning the intricacy of the intellectual and historical matrix of Eurocentrism, as well as for shaking off such a macula, or even entirely dismantling such a way of thinking. The agents of such a game-changing phenomenon that is part of the contemporary zeitgeist have been mainly those who, thinking from a locus of enunciation situated in the margins or outside Western scholarship and history, have advanced theories under the banners of post-colonial theory,

11. See generally DECOLONIZING EUROPEAN SOCIOLOGY: TRANSDISCIPLINARY APPROACHES 6 (Encarnación Gutiérrez Rodríguez et al. eds., 2010) [hereinafter DECOLONIZING EUROPEAN SOCIOLOGY] (presenting a confrontation of "European sociology with its epistemological premises and complex societal movements, questioning it as a hegemonic center").

12. See generally DECOLONIZING INTERNATIONAL RELATIONS 1 (Branwen Gruffydd Jones ed., 2006) (offering an alternate view of international relations outside of the "distorted Eurocentric thought"); THINKING INTERNATIONAL RELATIONS DIFFERENTLY (Arlene B. Tickner \& David L. Blaney eds., 2012) (presenting ideas about how international relations theory is produced outside the core sites of knowledge production).

13. See generally Thomas Duve, European Legal History: Global Perspectives (Max Planck Inst. For Eur. Legal Hist., Working Paper No. 2013-6), available at http://ssrn.com/abstract=2292666 (arguing that European legal history should be put in a global perspective).

14. See generally ANTONY ANGHIE, IMPERIALISM, SOVEREIGNTY AND THE MAKING OF INTERNATIONAL LAW (2005) (arguing that doctrines of international law were developed in a way to account between European and non-European environments).

15. See generally THIRD WORLD PERSPECTIVE, supra note 2 (offering an interdisciplinary approach to human rights from a decolonized perspective). 
subaltern studies, decolonial thinking, and the Third World Approach to International Law (TWAIL), among others.

But intellectuals who originally had thought from a Western standpoint have also developed such a critique. This might be the case of Santos, who defines modern rationality as an abyssal way of thinking. ${ }^{16}$ Santos describes his locus of enunciation as a multiple one: he "works" in a semi-peripheral country such as Portugal, and in the United States, and does his "field work" in Latin America and Africa." 7 This demonstrates the complexity of the standpoint from which he has developed his theory. Set originally in the North, Santos's critique of modernity appears to be an internal critique. Santos himself arrives at this conclusion in a text in which he reflects on his own intellectual trajectory and initially agrees with Walter Mignolo's assertion in the same sense. ${ }^{18}$ However, Santos states that the internal origin of his critique does not diminish its power and scope. ${ }^{19}$

Santos has divided his work into two periods: from the middle of the 1980 s to the middle of the $1990 \mathrm{~s},{ }^{20}$ and from then on. In the first phase, his overriding approach is that of his own variety of postmodern thinking-what he termed "oppositional postmodernism." Santos's postmodernism is committed to social emancipation in contradistinction to "celebratory postmodernism," which falls prey to skepticism.21 Oppositional postmodernism shares with mainstream currents the critique of universalism, linear history and progress, and hierarchical totalities. It also keeps the emphasis on concepts like margins, heterogeneity, plurality, and difference, as well as the constructivist, nonfoundationalist and anti-essentialist conception of knowledge. ${ }^{22}$ This postmodern approach was translated in Santos's legal scholarship into his engagement with pluralism, the mapping of law, ${ }^{23}$ the elaboration of a postmodern understanding of law, and the construction of a "new

16. Paradoxically, and because of the expansion of Western culture in the colonized world, those who think with a Western weltanschauung can also be born and socialized in the Third World, and not only in the West.

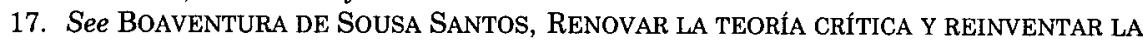
EMANCIPACIÓN SOCIAL 15 (2006) (Arg.), available at http://bibliotecavirtual.clacso.org.ar/ ar/ libros/edicion/santos/santos.html.

18. See Boaventura de Sousa Santos, From the Postmodern to the Postcolonial - And Beyond Both, in DEColonizING EUROPEAN SocIOLOGY, supra note 11, at 225, 232 n.2.

19. See id.

20. See id. at 225-26.

21. See generally STEPHEN R. C. HICKS, EXPLAININg POSTMODERNISM: SKEPTICISM AND SOCIALISM FROM ROUSSEAU TO FOUCAULT (2004).

22. See Santos, supra note 18 , at 228.

23. See Boaventura de Sousa Santos, Law: A Map of Misreading. Toward a Postmodern Conception of Law, 14 J.L. SoC'Y 279, 279-82 (1987). 
common sense." ${ }^{24}$ Santos even elaborated a reflection on human rights "in postmodernity," but his ideas of North-South dialogue, learning from the South, and his concern for the Third World were already present in an embryonic way. ${ }^{25}$

From the middle of the 1990s, his reflection has grown or shifted toward the South, colonial history, and what Santos defines as postcolonialism, which for him is not limited to postcolonial theory and subaltern studies, as in the case of the work of Dipesh Chakrabarty, ${ }^{26}$ but also includes decolonial thinking, as Santos entered in a dialogue with Enrique Dussel, Aníbal Quijano, and Walter Mignolo. Due to his own trajectory and such encounters, Santos came to see that some reformulations of his oppositional postmodernism were needed. ${ }^{27}$ One of them has to do with his viewpoint, which prompted a shift of perspective that Santos compares to the figure of Ariel-who rejects the possibility of siding with Prospero to be on the side of Caliban-and to the Gramscian idea of the organic intellectual whose self-reflexivity would ensure one is on the side of "all the oppressed peoples of the world."28

So, how can we characterize Santos's epistemological or theoretical position? Can he be described as an oppositional postmodernist who is inclined to deepen the postcolonial dimension of his thought? Or is he a postcolonial thinker with a postmodern mind? It is likely that the former would be thought to define his outlook in the first period and that the latter more accurately describes his current position, unless we follow his paradoxical description of his own thought as it stands today: "My proposal for the reconstruction of social emancipation from the South and by learning from the South allows for oppositional postmodernity to be legitimately conceived of as more postcolonial than postmodern." 29 Is this a postmodern thinking that is more postcolonial

24. See generally BOAventura DE SOUSA SANTOS, TOWARd A NEW COMMON SENSE: LAW, SCIENCE AND Politics IN THE PaRAdigmatic TRANSiTION (1995) (tracing the historical process by which both modern science and modern law lost the balance between social regulation and social emancipation inscribed originally in the paradigm of modernity).

25. BOAVENTURA De SOUSA SANTOS, OS DiREITOS huManOS NA Pós-MODERNIDAde 1113 (1989) (Port.), available at http://www.ces.uc.pt/myces/UserFiles/livros/1097_Oficina\% 20do \%20CES_10.pdf.

26. See generally Ramón Grosfoguel, La descolonización del conocimiento: Diálogo critico entre Frantz Fanon y Boaventura de Sousa Santos, EL CORREO DE LA DIASPORA LATINOAMÉRICAINE (Aug. 29, 2012), http://www.elcorreo.eu.org/La-descolonizacion-delconocimiento-Dialogo-critico-entre-Frantz-Fanon-y-Boaventura (presenting a critical dialogue and commonalities drawn between the work of Santos and Fanon).

27. See Santos, supra note 18 , at $227,229$.

28. Boaventura de Sousa Santos, Nuestra America: Reinventing a Subaltern Paradigm of Recognilion and Redistribution, 18 THEORY, CULTURE \& SOC'Y 185, 213-14.

29. Santos, supra note 18 , at 232 n.2. 
than postmodern? Or is this a postcolonial thinking that is more postmodern than postcolonial? It appears that for Santos, and he is probably right, this difference does not count for much in the end.

Finally, it should not be forgotten that behind both postmodernism and postcolonialism lies the ghost of Marxism, which helped establish both but from which both have distanced. This is also Santos's position, for whom rescuing modern values and critiquing violence remains valid and goes hand in hand with, and beyond, the critique of critical theorysuch as Marxism-and capitalism:

The idea of postmodernity I subscribed to aimed to radicalize the critique of Western modernity, proposing a new critical theory, which, unlike modern critical theory, would not convert the ideas of an emancipatory transformation of society into a new form of social oppression. Such modern values as liberty, equality and solidarity have always seemed fundamental to me, as fundamental, indeed, as the critique of the violences committed in their name, and the denunciation of their poor concrete fulfillment in capitalist societies. ${ }^{30}$

\section{ABYSSAL THINKING AND EPISTEMIC INJUSTICE}

Santos characterizes modern Western rationality as an abyssal way of thinking. There are different species or ways of thinking in the modern West, and abyssal thinking is not exclusive to Western cultures. But the focus of analysis and critique of Santos is the more idiosyncratic Western way of thinking, which has dominated the production of knowledge in modernity. ${ }^{31}$ Portraying modern reason as an abyssal thought is a bold idea in as much as it defines the logic or the architecture of Western thought. Santos uses the metaphor of the abyss to convey the thesis that Western thinking organizes the production and validation of knowledge along the lines of a precipice-a veritable sheer drop like the one encountered at the top of a mountain or found in the depths of the sea-that separates theories produced in the North from those elaborated in the South. ${ }^{32}$

30. Id. at 226. In the "pre-history" of Santos's intellectual development (1977-mid 1980s) is his research on questions like that of socialism. See also BOAVENTURA DE SOUSA SANTOS: ARTICLES, http://www.boaventuradesousasantos.pt/pages/en/articles.php (last visited Apr. 15, 2014).

31. Santos, supra note 6 , at 45 .

32. Id. 
For Santos, modern international law and modern knowledge are two exemplars of abyssal thought-two spheres that obey different dynamics but are "interdependent." 33 In the genealogy of abyssal thinking, Santos attaches a "historical precedence" to law for the production of this type of knowledge. ${ }^{34}$ The modern legal figure of the "global lines" that already separated Europe in the sixteenth century from the colonial zone was central to the construction of modern international law, as evidenced by Carl Schmitt. ${ }^{35}$ Among the first instances of these vast geographical coordinates are the "amity lines," which were agreed to as a secret clause in the 1559 Cateau-Cambrésis Treaty between France and Spain. ${ }^{36}$ These lines established a distinction between territories on this side of the line, in the landscape of Europe, where France and Spain were allies and law would apply, and territories to the other side of the line in the colonial world, where no law was in force apart from the rule of violence and France and Spain acted as enemies. ${ }^{37}$

Modern international law was one of the founding and key instantiations of abyssal thinking. Acting as a justification for colonization and the war of conquest, as in the case of Francisco de Vitoria's theory, ${ }^{38}$ international law contributed to the legitimation of imperialism and its success in history. Apart from creating a global political order, colonialism also gave rise to a global epistemological order. The legal and geographical lines separating metropolises and colonies on the map of the early modern world had consequences in the arena of epistemology. On this basis, it is possible to say that one of the founding moments of abyssal or modern thinking is precisely that of the colonization of the world. We are here in the terrain of the "geopolitics of

33. Id. at 46 .

34. Id. at 48 .

35. CARL SchmitT, THE Nomos OF THE EARTH 86-89 (G.L. Ulmen trans., 2006).

36. Before the amity lines there were the pole-to-pole rayas traced and sanctioned by the Spanish Pope, and head of the infamous Borgia family, Alexander VI in the bull Inter Caetera (1493), which were incorporated into the Treaty of Tordesillas (1494). This treaty divided the world between Spain and Portugal: Spain could conquest and incorporate to its empire all the lands found to the West of the raya, a meridian located 370 leagues to the West of the Cape Verde islands, or at longitude $46^{\circ} \mathrm{W}$ in today's notation, while the territories to the East of the line were to be colonized and appropriated by Portugal. Above all, the Tordesillas lines do not fit completely Santos's concept as they did not distinguish between the "Old" and the "New" World, but between the realms of two European empires within the "discovered" world. See id. at 89-99.

37. See id. at 92-94; Santos, supra note 6, at 49 n.10.

38. See generally Francisco De Vitoria, Political Writings (Anthony Padgen \& Jeremy Lawrance eds., 1991) (comprising the core of Vitoria's theories); see also Antony Anghie, Francisco de Vitoria and the Colonial Origins of International Law, in LAWS OF THE POSTCOLONIAL 89, 89-90 (Eve Darian-Smith \& Peter Fitzpatrick eds., 1999). 
knowledge"--knowledge considered in relation to modern history and colonialism. ${ }^{39}$

In the sphere of knowledge, global lines separate ideas coming from the North from those coming from the South. Abyssal thinking is a technology of knowledge that specializes in making distinctions and in radicalizing them. It creates two markedly different camps or species of knowledge. To the North of the line are those notions to be taken as truthful and universal. To the South-the colonial zone or the Third World-the notions that are classified as opinions or taken simply as false; or are limited by their local origins, or are not worthy of consideration, or cannot participate in the production of knowledge, or are beyond recognition, or do not exist as such. ${ }^{40}$ This distinction creates a hierarchy that locates in the superior levels those knowledges coming from the metropolitan centers of empire, which are assumed to be universal and, as a consequence, possess the monopoly of truth and the criteria to decide truth claims.

Abyssal thinking excludes the possibility of "copresence" of both kinds of knowledge at each side of the line. ${ }^{41}$ This is the case of Hegel's notion in "World History" in which Europe is in the present, Asia is in the past, and the Americas are relegated to the future, a constellation of ideas in which only the present is the territory of the "Spirit." 42 The complex epistemological process encompassed by abyssal thinking constitutes or creates a truthful cognitive injustice..$^{43}$

The relegation of Southern knowledges to nonexistence or invisibility was not achieved only by the actualization of the epistemological discourse. In sustaining and enacting abyssal theories of knowledge, colonization displayed its destructive capacity by plundering non-Western knowledges. It also triggered a five-century long "epistemicide"-the annihilation of entire cultures, languages, religions, and knowledges ${ }^{44}$ - with the subsequent waste of centuries or millennia of experience and creativity of too many civilizations. ${ }^{45}$ The obliteration of other knowledges continues today as the current global dynamics of

39. See Mignolo, supra note 1 , at 57-58.

40. See Santos, supra note 6 , at $45-48$.

41. Id.

42. See Georg Wilhelm Friedrich Hegel, The Philosophy of History 53-79 (J. Sibree trans., 1956).

43. See Boaventura de Sousa Santos, Introduction: Opening up the Canon of Knowledge and Recognition of Difference, in ANOTHER KNOWLEDGE, supra note 5, at xix-xxi.

44. Santos, supra note 6 , at 74 .

45. See generally Boaventura de Sousa Santos, A Critique of Lazy Reason: Against the Waste of Experience, in THE MODERN WORLD-SYSTEM IN THE LONGUE DURÉE 157 (Immanuel Wallerstein ed., 2004) (analyzing the conflict between hegemonic, neoliberal globalization, and counterhegemonic globalization on developing countries). 
knowledge can be characterized by colonial cognitive legacies and defined, in a substantive way, by the "coloniality" 46 of knowledge or what can be called the "coloniality of epistemology." Former colonial societies or neocolonies continue to be mere objects of analysis for the former Northern empires or neocolonial powers. Those colonial societies are deprived of the condition of agents of practices and authors of theories and are assigned the role of passive spectators of events with hypothetical worldwide significance, as well as recipients of Western false universals.

\section{EPISTEMOLOGIES OF THE SOUTH}

Santos's epistemological reflection departs from a selfunderstanding of the viewpoint and the political and intellectual context from which it emerges. Adopting the Global South as locus of enunciation allows for a vision of the world that is clearly different from the image of the world constructed from the position of the North. The World Social Forum and the Davos World Economic Forum embody these two perspectives that, at times, are so dissimilar as to appear to be speaking of different worlds. 47 The epistemologies of the South are historically grounded in the sense that they are born from history, although not from the "universal history" preached by the North, ${ }^{48}$ but the history of modern imperialism and anticolonial resistance. The name or the concept of the "South" stands for the "systematic suffering" of societies and communities that have been the victims of the violence and devastation unleashed by global capitalism, colonialism, and patriarchy. ${ }^{49}$ However, the two are intertwined-the South is embodied by marginalized communities living in the North and the North can be found in the privileged sections of the South. ${ }^{50}$

The theoretical context of these new epistemologies is described by Santos as a crisis of Eurocentric theory, including Critical Theory such as Marxism and the Frankfurt School. ${ }^{51}$ Social groups such as peasants, indigenous peoples, women, and the unemployed continue to fight against current colonial legacies and have produced important social

46. See generally Aníbal Quijano, Coloniality of Power and Eurocentrism in Latin America, 15 INT'L Soc. 215 (2000) (elaborating on the concept of coloniality and its implications in the contemporary world order).

47. See Boaventura de Sousa Santos, Introducción: Las Epistemologias del Sur, in FORMAS-OTRAS: SABER, NOMBRAR, NARRAR, HACER 9, 11-12 (Alvise Vianello et al. eds., 2011) (Spain).

48. See id. at 17.

49. See id. at 16.

50. See id.

51. See id. at 18. 
and global changes but have remained invisible for Eurocentric theory. Social and political movements outside of Europe are of no interest for Critical Theory or cannot be seen due to the blinders created by Eurocentrism. ${ }^{52}$ We should not lose sight of the fact that colonialism did not occupy a place in the research carried out by Theodor Adorno and Max Horkheimer. ${ }^{53}$ Compounding the lack of communication between struggles in the South and theory in the North-and contrasting with classical agents of change like the working class-some communities in the South who fight injustices today do not live in cities but in the mountains or jungles and speak vernacular languages. Those communities imagine their societies and the world using concepts that are far removed from those of Western theory. ${ }^{54}$

To avoid the continuation of the destruction of the knowledges of the South, abyssal thinking needs to be destabilized and resisted and a "new kind of thinking"-a post-abyssal way of thinking-needs to be constructed. ${ }^{55}$ The preparation of the conditions that allow a postabyssal thinking to emerge is a complex task. Western theory has to be deprived of its abyssal characteristics, among them, its claim to universality and the monopoly of truth. The critique of universalism consists of a negative universalism, one that precludes the possibility of any universal or general theory. ${ }^{56}$ At the same time, a "gigantic" decentering effort needs to be advanced by scholars and activists. Those standing on the northern side of the line can perform this as a selfdecentering project, as evidenced by the shift already performed by Santos himself, or as a critique advanced from outside the West. Such an abandonment of the position of the center in the production of knowledge could encourage those thinking from the Western locus of enunciation to "situate [their] epistemological perspective on the [history and] social experience of the other side of the line."57

In this new way of thinking, a second interlocutor should be acknowledged or reestablished. There is a search for knowledges, such as ancestral knowledges, about other ways of living together. ${ }^{58}$ Here, non-Western knowledges are validated as carriers of truth, and Southern voices' active role as agents or subjects of knowledge is recognized. These voices are seen as relevant, comprehensible, and not as merely local and, therefore, worthy of analysis and dialogical

\footnotetext{
52. See id. at 21.

53. See id.

54. See id. at 15

55. See Santos, supra note 6, at 53.

56. See Santos, supra note 47 , at 17 .

57. See Santos, supra note 6, at 66.

58. See Santos, supra note 47 , at 12 .
} 
engagement. A post-abyssal thinking secures the existence of knowledges on both sides of the line in equal co-presence and dismisses Hegelian's temporal or historical exclusionary hierarchies created between peoples, their histories, and their knowledges. 59

This new hermeneutical strategy entails crossing or jumping the abyss and creating bridges through dialogue. Western knowledge reproduces itself and persists through a solipsist rationale or a monologue enacted by Western subjects-a paradoxical dialogue in which only one speaker participates (i.e., the Western subject who speaks from Europe or North America). By contrast, at the core of the epistemologies of the South lies a dialogical dynamic, as they are built in the inclusive atmosphere of the "infinite experiences of the world" in which a "plurality of heterogeneous knowledges" inhabit or converge. ${ }^{60}$ This is a dialog between different cultures that are set on an equal standing, an intercultural dialogue in which knowledge is understood as interknowledge. Non-Western or indigenous understandings of the world have a place and a voice in this new forum. Above all, this is not about dismissing or breaking with Western thinking, which remains a welcome participant once it has been deprived of its abyssal ballast. A dialogue conceived in such wide terms cannot be termed anything other than an "ecology of knowledge," one that replaces the monoculture of the dominant epistemology of the North and that allows and promotes a real intercultural dialogue. ${ }^{61}$

\section{The Abyssal Understanding of Human Rights}

We can develop an interpretation of the theory and history of human rights on the basis of the concept of abyssal thinking. The theory and the historiography of human rights can be defined as another archetype of a theoretical field structured by an abyssal logic. The canon of the hegemonic philosophy of human rights includes thinkers like Thomas Hobbes, John Locke, Jean-Jacques Rousseau, Kant, and Hegel, who have contributed substantially to the elaboration of modern theories of natural rights in the context of political upheavals like the English Civil Wars and the French Revolution. Human rights were conceived in the context of the demise of absolutism and the formation of modern democratic states and became constitutional law with the Bill of Rights and the Declaration of the Rights of Man. The charters of rights were in turn hailed as manifestos of the dawn and a triumph of

59. See HEGEL, supra note 42 , at 8-102.

60. See Santos, supra note 47, at 16-17.

61. See id. at 18. 
political modernity. After the scathing critique of individual rights mounted by Marx in the nineteenth century, the canon continued with thinkers like Jürgen Habermas, John Rawls, Emmanuel Levinas, JeanFrançois Lyotard, and Richard Rorty, ${ }^{62}$ who understood the crisis of modernity as actualized in the atrocities of World War II, and adopted this idea as their historical horizon of understanding. The Universal Declaration of Human Rights followed as a response to that crisis and operates as a cornerstone of the post-war international order.

In this light, while the events and landmarks of the history of rights occurred within the geography of Europe, or are interpreted according to European criteria, the history of the philosophy of rights does not extend to other historical figures or thinkers who approach rights from the perspective of the South. ${ }^{63}$ Colonialism and the movements of resistance and independence are not part of the history of human rights, and no Southern historical figures and philosophers are recognized as contributors to the theory of rights. The colonized peoples remain silent and dazzled spectators to the magnificence of Western accomplishments, and the intellectuals thinking from the standing point of the South are assigned the role of receptors of the standard theory of rights to which they cannot contribute.

Scholars have not even formulated the question about the existence of a modern history and tradition of human rights theory in the vast geography of the peoples colonized by European empires since the times of the sixteenth century. At least since the beginning of the Cold War, the Third World has been considered a territory in which human rights are violated, and the North is portrayed as the region of the world from where the standards were developed and where judgments about compliance and responsibilities are made. If ultimately, in a daring shift, a new genealogy of rights is outlined following the trail of suffering left by the history of modern imperialism and the resistance to it, a swift reaction can be heard in academic debates, countering such a move as incorrect and unsuitable to the very nature of rights. Equally, the idea of an extended canon of historical figures and philosophers of human rights that embraces those who have approached them from the perspective of the South is hastily dismissed as not complying with the criteria that identifies what human rights really are intertwined with notions of natural law, humanity, or subjective rights; or as interpretations with local repercussions that are devoid of any significance in the global debate; or as just the repetition or the echo of

62. See generally, e.g., The Politics of Human Rights (Belgrade Circle J. ed., 1999) (collecting essays and articles by Serbian intellectuals criticizing the repressive Yugoslav government).

63. See discussion infra Part V.A. 
Northern achievements and concepts that cannot be the object of serious consideration. ${ }^{64}$

\section{EPISTEMOlogies OF THE SOUTH AND POST-ABYSSAL HUMAN RightS}

The epistemologies of the South offer powerful insights about how to rethink human rights from the perspective of the victims of colonialism and global capitalism. A critique of some of the central claims of the Eurocentric theory of human rights is in order. First of all, the assumption of the European understanding of human rights as "the" theory of human rights is one that boasts of its universality while denying the existence or the validity of theories of rights coming from the South. No theory of rights, from the North or the South, can reclaim universality in Santos's negative universalism, which precludes the possibility of universal or general theories-among them those characteristic of Northern epistemologies. ${ }^{65}$ Second, the subject of the theory and history of rights needs to be decentered so that the locus of enunciation of concepts of rights does not reside exclusively in the West, but also in numerous standpoints scattered all over the Global South. This hermeneutical move goes beyond the deconstructive gesture of bringing the margins to the center. It is a labor of erasing or multiplying the center, so that there is no center anymore or so that centers emerge everywhere.

Relating the epistemologies of the South to the field of human rights can be the object of different interpretations or enactments. Elsewhere, I have attempted to put into evidence hermeneutical strategies that can contribute to decolonizing human rights, including rewriting the history of human rights. 66 Post-abyssal thinking requires that the chasm between Western and non-Western traditions of rights be crossed and a dialogue facilitated between them. In my view, this conversation can take at least two forms: the first form can be enacted by rewriting the history of human rights; the second can follow the path described by Santos as an intercultural dialogue. ${ }^{67}$

64. See Paul Gilroy, Darker than Blue: ON the Moral Economies of Black ATLANTIC CULTURE 3, 55-59 (2010).

65. See Santos, supra note 47 , at 17.

66. See José-Manuel Barreto, Decolonial Strategies and Dialogue in the Human Rights Field: A Manifesto, 3 TRANSNAT'L LEGAL ThEORY 1 (2012) (U.K.).

67. See SANTOS, supra note 10 , at $345-47$. 


\section{A. Rewriting the History of Human Rights}

This hermeneutical strategy strives to retrieve and validate the tradition of rights that has existed in the colonized world since the times of the conquest of America and that has grown out of resistance movements to modern imperialism. ${ }^{68}$ Sharing the core ancient and medieval tradition of natural law, humanism, and human dignity, two streams of natural rights arose at the dawn of modernity: the European, grounded in the push for democracy and against absolutism, and the non-European, grounded in resistance to colonialism and the movement for independence and decolonization. In consequence, it is possible to say that, to the South of the epistemological line that has sustained the hegemony of the Eurocentric theory of rights, there has also been a tradition that sits on an equal standing when defining human rights. An account of this other stream of the history and theory of human rights can follow the criteria suggested by Paul Gilroy to make more intricate the conventional "shallow" chronology of human rights constructed by the "myopic Europe-centredness" of human rights scholars. ${ }^{69}$ According to Gilroy, a new archive or genealogy of human rights needs to be constructed by listening to the voices of those who fought against modern colonialism, racism, and slavery:

It should begin with the history of conquest and expansion, and must be able to encompass the debates about how colonies and slave plantations were to be administered. At its most basic, this agonistic, cosmopolitan enterprise must incorporate the contending voices of Bartolomé de Las Casas and Juan Ginés de Sepúlveda.... The counter-narrative of human rights we require is evident in opposition to racial orders, in the struggles of indigenous peoples and in the post- and anticolonial pursuit of liberation from imperial domination. ${ }^{70}$

If we are to take into account Gilroy's suggestion, the history of human rights told from the perspective of the South indeed features those who defended the indigenous peoples of the Americas on the basis

68. Despite the fact that Santos finds the source of massive historical human rights violations in colonialism and the global North, Santos does not elaborate on the history of human rights struggles and concepts developed as a response, and in resistance to modern imperialism.

69. See GILROY, supra note 64 , at 55-59.

70. See id. at 57, 71-72. 
of their natural rights as in the cases of Bartolomé de Las Casas ${ }^{71}$ and Francisco Suárez. ${ }^{72}$ The opposite side of the debate is occupied by those like Francisco de Vitoria and Juan Ginés de Sepúlveda, who legitimized the war of conquest as a sacred war appealing to the natural rights of Spanish conquistadors and colonizers to trade and preach their religion. ${ }^{73}$ In a similar way, freed African slaves such as Olaudah Equiano and Ottobah Cugoano made use of the natural law tradition to campaign for the abolition of slavery in treatises published in London in the eighteenth century. ${ }^{74}$

The discourse of rights was also central to the justification of the movement for independence in the Americas toward the end of the eighteenth century and the beginning of the nineteenth century. The independence of the United States from the British Empire in 1776, Haiti from the French (Enlightened) Empire in $1804,{ }^{75}$ and most of the Latin American countries from the Spanish and Portuguese empires since 1810 was legitimized in part on the basis of theories of natural rights and the Rights of Man. In addition, bills of rights occupied a central place in the constitutions adopted by the new republics and contributed to the formation of the new independent states. ${ }^{76}$ Another key moment of this history is the political decolonization of Africa, Asia, the Middle East, and the Caribbean, mainly in the second half of the twentieth century. The contribution of decolonization to human rights can be seen above all in the group of international treaties that were adopted once the newly liberated nations took seats in the United Nations. Among the key contributions to the human rights tradition made by the 1981 African Charter on Human and Peoples' Rights are

71. See generally José-Manuel Barreto, Imperialism and Decolonization as Scenarios of Human Rights History, in THIRD WORLD PERSPECTIVE, supra note 2, at 140 (presenting a view of human rights progression from the Global South rather than the European perspective).

72. See generally Enrique Dussel, Las Casas, Vitoria and Suárez, 1514-1617, in THIRD WORLD PERSPECTIVE, supra note 2, at 172 (offering a recounting of the work of Spanish philosophers from the first Modernity).

73. See Barreto, supra note 71, at 144-55.

74. See generally, e.g., OtTobah Cugoano, Thoughts and SEnTIMENTS on THE EviL AND Wicked Traffic of THE Slavery AND CoMmerce of THE HuMAN SPECies (1787) (providing an overview of the author's experiences and reactions to his enslavement); Ol.AUDAH EQUIANO, THE INTERESTING NARRATIVE OF THE LIFE OF OLAUDAH EQUIANO, OR Gustavus VASSA, THE AFRICAN (1789) (detailing the life of the author and his search, and eventual attainment, of freedom from slavery).

75. See generally, Anthony Bogues, The Dual Haitian Revolution and the Making of Freedom in Modernity, in THIRD WORLD PERSPECTIVE, supra note 2, at 208 (outlining the Haitian Revolution in the context of conquest and "the fall of 'natural man," and later, African slavery and colonialism).

76. See Barreto, supra note 71 , at $155-59$. 
the Declaration on Decolonization and the Declaration against Racial Discrimination, as well as the introduction of the rights of peoples and the right to self-determination. It was also after colonization faded that the right to self-determination of indigenous and tribal peoples was internationally recognized by the 1989 International Labor Organization Convention No. 169, and more recently in the 2007 United Nations Declaration on the Rights of Indigenous Peoples. ${ }^{77}$ This area of the international human rights regime can contribute to protecting people in the South from the violence of empires and transnational corporations.

There is also a need to acknowledge the inputs to the human rights tradition made more recently by the Civil Rights and Anti-Apartheid movements and by the struggles against right-wing and leftist dictatorships and totalitarian regimes in Latin America and Communist Europe in the $1980 \mathrm{~s}$. Last but not least, the emergence of indigenous groups, social movements, and entire peoples fighting today in the Global South against abuse and devastation caused by contemporary states, empires, transnational corporations, and international financial institutions should be commended. Embedded in these social and political movements is an intellectual tradition of resistance to imperialism, to the legacies of colonialism, and to the violence of the state, a tradition in which natural, civil, and human rights are central. This alternative canon includes the works of figures such as Frederick Douglas, Sojourner Truth, W.E.B. du Bois, Martin Luther King, ${ }^{78}$ Gandhi, the Dalai Lama, Nelson Mandela, Rigoberta Menchú, and Upendra Baxi, among others. All these underestimated historical landmarks and marginal thinkers should feature prominently alongside the milestones of the dominant but incomplete Eurocentric history and theory of human rights.

\section{B. Intercultural Reconstruction of Human Rights}

For Santos, as long as human rights remain based on Eurocentric universal values they will remain a part of globalization from above, a process in which a local vision of rights coming from Europe becomes global. ${ }^{79}$ Multiculturalism, or a reworking of human rights as an intercultural construct, is necessary to ensure that rights remain

77. See id. at 159-64.

78. See generally Vincent W. Lloyd, Love, Justice and Natural Law: On Martin Luther King, Jr. and Human Rights, in THIRD WORLD PERSPECTIVE, supra note 2, at 237 (discussing the implications of King's work in human rights as a rhetorician and how his work can be used in a "human rights "theory").

79. See Barreto, supra note 71 , at $155-59$. 
globally meaningful while acquiring local legitimacy, as well as imagining a. "contra-hegemonic politics of human rights" in the times of globalization. 80

To remain relevant in this restructured global debate, the Western understanding of human rights needs to drop the universality that characterizes it. Some of the basic concepts underpinning human rights contain the claim to universal validity: the idea of a universal human nature that is apprehended by reason; that of a human dignity that stands in a superior echelon above the dignity of animals and nature, and the need for protecting individual autonomy by a society organized as an aggregate of individual subjects. ${ }^{81}$ The abandonment of universal human rights creates the conditions for other visions of rights to appear and to be part of the ensuing conversation.

Above all, multiculturalism does not always lead to a greater protection of individuals and societies, as was the case when China and other countries of South Asia used the call for respect of cultural differences or "East-Asian values" to entrench neoliberal economic policies regardless of their consequences for the life and democratic freedoms of their citizens. As transcultural dialogue is no guarantee of progressive politics and respect for human rights, an agreed-on criterion is needed to define them. ${ }^{82}$

The atmosphere that fosters a transnational dialogue is one of richness, variety, and multiplicity of values and cultures converging on equal terms from all the corners of the world. Recognition, inclusiveness, and mutual intelligibility are the sine qua non for a meaningful encounter in which different visions are taken seriously. Thus, non-Western, Third-World, and aboriginal perspectives become sources for a "mestizo conception of human rights." 83 Such an understanding of rights does not appeal to universals and sees itself as a "constellation of local meanings that are mutually intelligible."84 However, the new dialogue faces difficulties, and the knowledges involved need to comply with certain requirements. Other cultures can have dissimilar notions of human dignity that are not usually translated into human rights. And ideas that are related, commensurable, or analogous to human dignity can be more or less encompassing and need to be taken as incomplete as a necessary condition for a plurality of worldviews to coexist. ${ }^{85}$

80. See SANTOS, supra note 10, at 352-53.

81. See id. at 353.

82. See id. at 364 .

83. See id. at 357 .

84. See id.

85. See id. at 356 . 
This incompleteness is actualized by a "diatopical hermeneutics," a concept drawn by Santos from the works of Raimundo Panikkar. ${ }^{86}$ Topoi are the basic concepts on which a culture is constructed-the grounding prejudices or the common sense of a culture at a given time.$^{87}$ But any topoi, no matter how strong and extensive it is within a culture, is weak or incomplete anyway. The limits of topoi cannot be seen from within a culture, but they are made evident when put in contact with topoi of other cultures. A thinking that follows a diatopical hermeneutics is aware of the incompleteness of all cultures involved and actualizes a dialogue in which participants have "a foot on each culture." 88 The advancement of such hermeneutics is not a task for a single author or culture. To construct knowledge in an intersubjective way requires contributions from a number of cultures and generations. ${ }^{89}$ Santos presents two cases of dialogue between cultures that follow diatopical hermeneutics by building on examples developed by Panikkar and Abdullahi An-Na'im.

The first is a dialogue between the topoi of human rights and the topoi of the Hindu "dharma." From the point of view of dharma, human rights are incomplete because they are unable to create a strong link between the part or the individual, and totality or reality. ${ }^{90}$ Western topoi focus on rights while leaving aside the need for individuals to find a place in the middle of society and the cosmos. On the other hand, Western topoi are strange to the idea of rights residing in nature and future generations. From the perspective of human rights, dharma appears incomplete as it concentrates on the value of harmony while condemning to invisibility injustices committed against individuals and excluding the contribution of social conflict to a less unjust and more harmonious society. ${ }^{91}$

Drawing from An-Na'im's work on intercultural dialogue, Santos also develops a diatopical hermeneutics by setting a dialogue between the topoi of human rights and the Muslim umma.92 According to less inclusive versions of Islamic culture, there are some irreconcilable differences between Shari'a and human rights principles. Among the more visible are those according to which umma would not allow equal rights to non-Muslims or women. ${ }^{93}$ For An-Na'im, the elaboration of a

86. RAIMUNDO PANIKKAR \& ARVIND SHARMA, HUMAN RIGHTS AS A WESTERN CONCEPT 32-33 (2007).

87. See SANTOS, supra note 10 , at 357.

88. Id.

89. See id. at 362-63.

90. See id. at 358-59.

91. See id.

92. See id. at 359-62.

93. See id. at 361 . 
transcultural understanding of human rights requires a reconstruction of the meaning of Shari'a in such a way that a positive relationship between Shari'a and human rights is possible. ${ }^{94}$ This reinterpretation can be developed by retrieving the sources of Islamic law, dating back to the foundational period of Mecca, that grant equal dignity to all without distinction of faith, gender, or race, but that have been suspended since the enthronization of the more restrictive jurisprudence of the period of Medina. ${ }^{95}$ On its part, umma represents a possibility for strengthening collective rights in the framework of a Western conception of rights trapped by individualism and of developing notions of duty in relation to the community, the world, and the cosmos. ${ }^{96}$

These attempts to show the possibility of establishing a dialogue between cultures have clear limitations. Rather than cultural explorations, they appear to be a philosophical analysis of isolated ideas central to their respective cultures. The cultural or anthropological analysis that is implied, or should be at work, in an intercultural dialogue loses force and complexity when single words or concepts are put next to each other without an elaborated connection to the social life from which they emerged, to the historicity and plasticity of every culture, or to the internal heterogeneity of traditions. Without a strong relation to cultural contexts, a dialogue between cultures can become superficial, misleading, or can even neglect and obliterate one or both of the cultures involved. An intercultural dialogue is a collective task that requires the participation of individuals socialized within their respective cultures-the native's point of view-as well as the presence of experts with an anthropological understanding of the traditions and with a grasp of the history and languages involved in the conversation. Such experts are needed to perform the multiple tasks of informants, interpreters, and translators. Above all, this objection has also been formulated to well-established anthropologists who have attempted similar studies. ${ }^{97}$

94. See id. at $360-62$.

95. See id.

96. See id. at 359 .

97. This could be the case of Clifford Geertz's comparison between Islamic haqq, Hindu dharma, and Malay adat. Despite its shortcomings (I am grateful to Ismail Warscheid for providing me with a lead into this insight), this was intended as an example of the capacity of Anthropology to bring "incommensurable perspectives on things, dissimilar ways of registering experiences and phrasing lives, into conceptual proximity," weakening or dismantling perplexities and paradoxes that can emerge when cultures draw closer. This approach to legal encounters is based on the concept of law as culture or as "legal sensibility"; of legal encounter as a dialogue with "other modes of thought and feeling"; and of ethnographic analysis of law as "cultural contextualization" or as exploration of the 
Another outcome of a cross-cultural dialogue on human rights is the one proposed by Makau Mutua, which is quoted by Santos but not discussed in detail. ${ }^{98}$ As an alternative to the Western universalist conception of human rights that is imposed on the rest of the world and on the basis of which the inhabitants of the Third World are taken as savages to be saved of themselves by European projects, Mutua proposes to construct a multicultural understanding of human rights..$^{99}$ This extended conceptualization of rights departs from cultural pluralism and searches for a common universality that includes the contributions of all cultures. Not distant from a Marxist critique of liberal rights, Mutua's multicultural understanding of the corpus of human rights starts by "balancing ... individual and group rights, giving more substance to social and economic rights, relating rights to duties, and addressing the relationship between the corpus and economic systems." 100

\section{CONDITIONS AND POLITICS FOR AN INTERCULTURAL DiALOGUE ON} HUMAN RIGHTS

Santos has not only considered the epistemology of human rights, but he has also worked on the practical conditions that underline or make possible the consolidation of human rights as an emancipatory discourse at the global level. Developing a dialogue that follows the dynamics of a diatopical hermeneutics requires compliance with a series of cultural requisites-which could easily be taken as epistemological musts-and has to bear in mind the historical, sociological, and political conditions and problems in which the intercultural dialogue on human rights is already set, which in turn are embedded in the history of the interaction between Western and non-Western cultures. However, before detailing the requisites and the socio-political context, let us consider some preconditions that Santos renders necessary for starting such a dialogue.

For Santos, the capacity of human rights discourse to become a powerful beacon of resistance and emancipation in global politics depends on radically distancing itself from hegemonic neoliberalism and on being part of a broader strategy for social and global

"cultural foundations of law." CuFFord GEERTZ, LOCAL KNOWLEDGE: FURTHER ESSAYS IN INTERPRETATIVE ANTHROPOLOGY 174-75, 187-214, 234 (3d ed. 2000).

98. See Santos, supra note 9, at 26.

99. See Makau Mutua, Savages, Victims, and Saviors: The Metaphor of Human Rights, 42 HARV. INT'L L.J. 201, 243-45 (2001).

100. Id. at 243 . 
transformation. ${ }^{101}$ No cross-cultural dialogue can be the consequence of imposition if we are to break with the history of cultural imperialism. This is perhaps the sine qua non of this proposal, and it is the crucial one of a set of prerequisites or meta-conditions that need to be met for a proper dialogue to exist. The cultures involved need to choose and accept each other as interlocutors. They also have to reach an agreement about the topics of the dialogue, as well as about the time in which the exchange is going to take place. ${ }^{102}$ Is the West interested in entering into a dialogue with non-Western or Third World cultures and countries? Are the latter inclined to reciprocate? Is such a dialogue always necessary or desirable? No dialogue can be forced upon cultures or peoples because such an encounter would be inevitably shattered by violence.

As for the cultural settings, they have to do with the need for a culture to have a self-critical consciousness, or at least an intuitive suspicion about its incompleteness (i.e., about its own incapacity to answer or resolve all the questions or problems it faces). Cultures must not see themselves as complete if they are to be able to imagine that their own concerns can be settled by another culture.103 Second, disagreements about competing conceptions of equality and difference are to be resolved by privileging equality over hierarchies and protecting difference when identities are at stake.104 This cultural requirement appears contradictory when each of its two tenets is considered in light of the other. Although progressive, it can be met with immediate and stark opposition from non-Western cultures from the outset, putting the very possibility of dialogue in peril. Third, as heterogeneity is a feature of any culture, when getting into an intercultural conversation, it is also necessary to prefer the wider versions of the interacting culture or that with the "widest circle of reciprocity within that culture," or "the version that goes farthest in the recognition of the other." 105 Santos mentions as an exemplar the selection of the interpretation of the Qur'an that recognizes the fair treatment of both men and women, Muslims and non-Muslims. ${ }^{106}$

The other instantiation of this rule suggested by Santos looks inadequate, or even appears to point to the possibility of replacing the criterion of the "widest circle of reciprocity within that culture" by that of the "comprehensive version" of a culture. If a dialogue between

101. See Santos, supra note 9 , at 3.

102. See id. at $26-28$.

103. See id. at 25-26.

104. See id. at 28.

105. See id. at 26 .

106. See id. 
human rights and other cultures is attempted, Santos proposes to choose the socialist over the liberal conception of rights on the basis that the former extends equality to both the political and economic realms. ${ }^{107}$ Apart from the historically counter-evident character of the justification, Santos puts aside the principle of interdependency between generations of rights, which has been one of the recent conquests of the more progressive interpretations of human rights. Santos also forgets that a third generation of rights, born out of anticolonial struggles, is also a part of a more comprehensive conceptualization of rights and includes the rights to self-determination, development, and the environment. Coming from outside and inside the West, this set of rights has been a part of the international law of human rights for decades. In the case of human rights, not the widest version but the more comprehensive version of a culture is more appropriate for constructing a fertile intercultural conversation.

The historical context in which this dialogue is attempted is one of the barriers that must be confronted. For Santos, as the interlocutors share a history of colonial exchanges, it is often the case that one of the cultures involved has been the victim of longstanding violence and human rights violations committed by the other. In addition, the consequences of the history of colonial violence are not exhausted in societal wounds and suffering. Due to its pervasive presence in all spheres of life, such violence contributed to the very constitution of the culture it violated. Is a diatopical hermeneutics possible in such circumstances? Is the Western hegemonic culture ready to drop the universalism on which it is based and has thrived? Is the dominant culture prepared to listen to the topoi of subalternized cultures that were once banned? Is it fair to treat with equality two traditions that are related by a history of unequal exchanges?108

The dialogue on human rights is also set in a complex sociological context. Firstly, it is set against the background of the tension between social regulation and emancipation, which Santos understands as the two societal constituent poles of modernity. This dyad has been replaced by the crisis of emancipatory politics, which cannot aspire to a better world as emancipation is today trapped in a dystopian future of negative social expectations, or in the entrenched idea that there is no alternative to global capitalism. Secondly, it is set in the context of the tension between state and civil society, which has been transformed or distorted by neoliberalism making the interventionist state weaker and therefore less able to guarantee human rights of the second generation.

107. See id.

108. See id. at 23-24. 
And lastly, the tension between nation-state and neoliberal globalization, which has translated into erosion of the power of states to guarantee rights vis-á-vis transnational powers, including corporations. ${ }^{109}$ Contemporary globalization has put into evidence that social processes do not occur only at the national level but also, and substantially, at the global level, which has occurred since the beginning of modernity with the formation of the world system. Such a new insight has led to an intellectual shift from the national to the global level as the scenario in which social and political phenomena like domination and emancipation develop. The field of human rights is one in which this change is patent because of its international legal recognition and worldwide political currency. ${ }^{110}$

The third sociological tension gives way to the political scenario of the conflict between globalizations from above and from below. This confrontation has been accompanied by the phenomena of cultural fragmentation and the rise of identity politics, which highlight the issue of human rights as culture and pose questions about the local legitimacy of human rights. ${ }^{111}$ The question of legitimacy has already been answered by the project of intercultural dialogue. Universal human rights are a globalized localism, as the conception of human rights that emerged in the West has been extended all over the world as part of the process of globalization from above. To have local legitimacy and be a part of the push for a globalization from below, human rights need to abandon their claim to universality and should be replaced by a multicultural understanding of rights. ${ }^{112}$

Santos is aware of the power relations underpinning any attempt at setting encounters and hybridization between the North and the South-a consciousness that is defined as one that questions what, for whom, and in which context such a dialogue happens ${ }^{113}$-as well as the economic conflicts involved. ${ }^{114}$ Even if such conflicts are not discussed in detail ${ }^{115}$ Santos describes the core political conflict of the present as that between the intensification of the hegemonic or neoliberal globalization, or globalization from above, and the thrust of subaltern or insurgent cosmopolitanism, counter-hegemonic globalization, or globalization from

109. See id. at 3-5.

110. See id. at 5 .

111. See id. at 6.

112. See id. at 11.

113. See Santos, supra note 18 , at 228 (presenting a set of questions characteristic of the geopolitics of knowledge).

114. See Santos et al., supra note 5, at xl-xli.

115. Reservations are also made about the weak presence of the analysis of racism, and of the insights of feminism in Santos's work. 
below.116 Globalization from above includes both globalization of localisms-such as the English language or fast food or pop music from the United States-and its twin process of localization of globalisms, or the consequences of the global in local settings: distortion, disintegration, or exclusion (e.g., deforestation to pay external debts or conversion of agriculture of subsistence into one for export as a consequence of restructuring plans).

Counter-hegemonic globalization is the transnational resistance to neoliberal globalization, which unites local/global social movements and organizations that represent "classes and social groups" that have been victims of the destructive consequences of globalization from above. Thus, the historical subject or the agency of this insurgent cosmopolitanism resides, among others, in South-South and SouthNorth dialogues and networks of social movements and progressive nongovernmental organizations (NGOs); international trade unions; women's organizations; indigenous, ecological, and alternative development movements; intellectual movements that adopt nonimperialist, subaltern, and postcolonial positions; and NGOs, human rights organizations, and social movements that defend those oppressed by capitalism, authoritarianism, and imperialism. The World Social Forum would be "the most accomplished manifestation" of insurgent cosmopolitanism, 117 but Santos is quick to emphasize that counterhegemonic globalization is not made up exclusively by those who are victims of exploitation by capitalism-that is, the working class-but also by those who are socially excluded or are victims of racist, sexual, and religious discrimination. ${ }^{118}$ As a consequence, globalization from below is not a movement characterized by uniformity. On the contrary, it is committed to both equality and difference, and to autonomy and local identities, and cannot be based on a single or general theory of emancipation. ${ }^{119}$

As a consequence of the struggles advanced by social movements and progressive NGOs opposing neoliberal globalization over the last decades, alternatives to the North-centric conceptions of human rights have emerged. In these other visions, Santos says that "the global North and its imperial domination over the south-now intensified by neoliberal capitalism - was indeed the root source of the most massive

116. See Santos, supra note 9 , at 11.

117. See SANTOS, supra note 10 , at 351-52, 354-55.

118. See Santos, supra note 9 , at 11.

119. See id. at 10. See generally Boaventura de Sousa Santos, The World Social Forum and the Global Left, 36 POL. \& Soc'Y 247 (2008) (explaining the development of the World Social Forum in the context of left thinking and social movements and presenting arguments on the organization's future). 
violations of human rights." 120 However, Santos only mentions such new approaches without describing or analyzing them, nor making it clear if by these he means those conceptions that could come out of the intercultural dialogue he proposes. In any case, despite his gaze at the consequences for human rights of the history of modern imperialism, Santos fails to consider the tradition of anti-colonial natural law, rights of man, and human rights that has evolved since the times of the resistance to the conquest of America. Finally, the presence of these new concepts makes the field of rights rather "contentious," which, strangely, for Santos, constitutes a "problem" and not the fertile soil for new possibilities. ${ }^{121}$

Santos's theorization of emancipatory human rights includes cultural, historical, and sociological considerations, as well as the analysis of the political strategies that could advance the task of mainstreaming, in theory and practice, a post-abyssal conception of human rights. In addition, projects in which Santos has been involved as a promoter or participant, such as "ALICE-Strange Mirrors, Unsuspected Lessons: Leading Europe to a New Way of Sharing the World Experiences," 122 the Popular University of the Social Movements, ${ }^{123}$ and the World Social Forum, can be taken at least as partial historical incarnations of his more theoretical considerations.

\section{CONCLUSION}

Santos's epistemologies of the South offer a characterization of modern reason, a critique of Eurocentrism, and a new and counterhegemonic theory of human rights fit for today's social movements for global justice. As part of the enterprise of colonial exclusion, abyssal or modern thinking traced a line that created a chasm between knowledges coming from the North and from the South. It erected a hierarchy in which the former enjoys validity and is in possession of the criteria to decide on truth claims, while the latter, in a case of cognitive injustice and as a result of a veritable epistemicide, is condemned to irrelevance, falsehood, incomprehensibility, absence, or invisibility. For the project of global justice to advance, epistemic justice must be

120. Santos, supra note 9 , at $5-6$.

121. Id.

122. ALICE: STRANGE MirRoRS, UNSUSPECTED LeSSONS, http://alice.ces.uc.pt/en/ (last visited May 14, 2014).

123. Boaventura de Sousa Santos, The Rise of the Global left: The World SOCIAL FORUM AND BEYOND 148 (2006) (discussing Santos's proposal to the World Social Forum for the creation of a Popular University "with the purpose on enabling the selfeducation of activists and leaders of social movements"). 
achieved by dethroning the notion of the exclusive validity and universality of the knowledge produced by the North and by' retrieving marginalized knowledges and reclaiming their capacity for truth. A new relationship should be fostered between Western and non-Western knowledges, one in which a dialogue between subjects of equal epistemological standing exists. This encounter is a "confrontational" or critical dialogue between Southern knowledges and the hegemonic thinking of the Global North, both mainstream and Eurocentric critical theory.

Unveiling the abyssal character of modern knowledge and constructing or retrieving epistemologies of the South sets the theoretical scenario for rethinking human rights. The hermeneutics for a non-Eurocentric understanding of rights comprises three concepts, movements, or steps: critique, recognition, and dialogue. This sequence is present in Santos's post-abyssal or post-imperial notion of human rights, where he develops the critique by characterizing modern thinking as an abyssal one. Recognition in equal circumstances of Southern or non-Western knowledges is the second stage of Santos's reflection, which ends up in the call for intercultural dialogue. This three-part methodology is also used to supersede Eurocentric visions of human rights by other strands of emerging epistemological discourses, including the provincialization of human rights developed by Woessner (drawing from Chakrabarty), Twining's General Jurisprudence, and the decolonial critique of Eurocentrism coupled with the proposal of transmodern dialogue as elaborated by Mignolo and Dussel. ${ }^{124}$

The dialogical structure at the core of the ecologies of knowledge allows for, and gives impetus to, a cross-cultural exchange of ideas that would result in an intercultural, post-imperial conception of human rights. This new conception of rights should include the rights, "which the Western colonialist and capitalist modernity suppressed in order to build, upon their ruins, the monumental cathedral of fundamental human rights" or, in other words, the Eurocentric conception of human rights. ${ }^{125}$ The new rights, while signaling the destruction and wrongdoings perpetrated by colonialism, help create the conditions for the elaboration of a postcolonial or postimperial conception of rights, and they are: the right to knowledge; the right to bring historical capitalism to trial in a world tribunal; the right to a solidarity-oriented transformation of the right to property; the right to grant rights to entities incapable of bearing duties, namely nature and future

124. José-Manuel Barreto, Introduction: Decolonial Strategies and Dialogue in the Human Rights Field, in THIRD WORLD PERSPECTIVE, supra note 2, at 1, 3-5, 10-16.

125. Santos, supra note 9 , at 29. 
generations; the right to democratic self-determination; and the right to organize and participate in the creation of rights. ${ }^{126}$

Enabled by the replacement of the Western monocultures of knowledge by the richer and more diverse and fertile "ecologies of knowledge," post-abyssal thinking is having far-reaching theoretical and political consequences. It does more than contribute to the creation of an epistemic revolution. After reconstructing the concept of human rights, the epistemologies of the South can empower the social movements that today resist capitalism and colonialism and strive for transforming the structure of the global order. To do so, human rights need to incarnate not only in struggles and forms of resistance to oppression, but also become a fully fuelled discourse of emancipation. ${ }^{127}$

126. See id. at 28-35. This novel set of rights requires an analysis of its own and will not be made in this article.

127. See id. at 3 . 